\title{
An ICT Adoption Framework for Education: A Components Analysis
}

\author{
Sofiana Nurjanah, Harry Budi Santoso and Zainal Arifin Hasibuan \\ Faculty of Computer Science, Universitas Indonesia, Indonesia
}

\begin{abstract}
In the past ten years, adoption of Information and Communication Technology (ICT) in education is growing rapidly in almost every country in the world as an enabler to achieve the schools' goal. Despite many success reports on ICT adoption in education, there are many other studies conclude that ICT adoption in education is still a challenging problem. One of remaining challenge is how to identify and address key components for successful ICT adoption in school. The objective of this research is to propose some steps on how to identify and evaluate these components of ICT adoption using data-driven (bottom-up) approach. This method has been tested using primary data from schools in Indonesia. Some findings of this empiric research are some components which reflect the main components of ICT adoption in education. The identified components and their weights are: ICT Facilities (weight=20.35\%), Utilizing ICT in school administration (weight $=14.89 \%$ ), Utilizing ICT in teaching and learning (weight=12.71\%), User skill (weight=11.52\%), Policy (weight=6.61\%), Financial (weight=6.53\%), and Basic ICT Infrastructure (weight $=6.29 \%$ ). Last but not least, discussions regarding the findings are also presented.
\end{abstract}

Keywords: Information and Communication Technology, Education, Adoption, Utilizing ICT.

\section{Introduction}

In the past ten years, a vast number of reports conclude that adoption of Information and Communication Technology (ICT) in various domain show an increasing trend. In education sector, for instance, various ICT have been widely adopted to improve outcome of teaching and learning process. Figure 1 shows number of students per school computer in some countries.

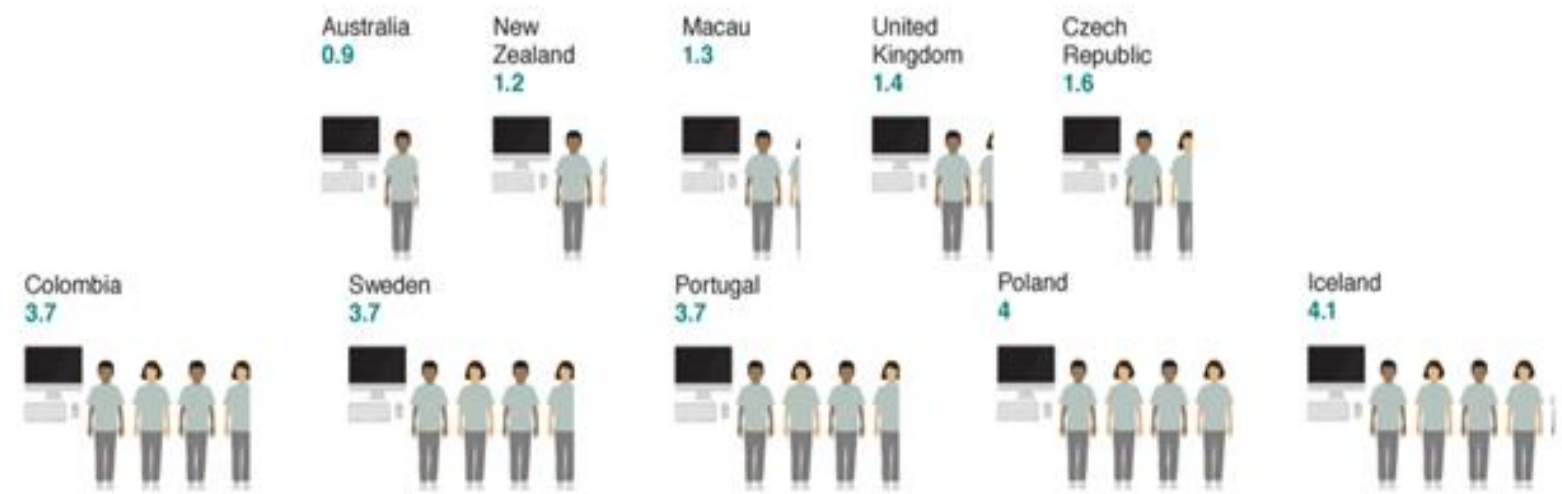

Fig. 1: Number of students per school computer in some countries (Source: OECD illustrated by BBC)

From Policy Information Center New Jersey U.S., 98\% of all schools in U.S. own computers, but only $85 \%$ are equipped by multimedia, Students attending poor and high-minority schools have less access than students attending other schools. $64 \%$ of U.S. schools have access to the Internet, up from $35 \%$ in 1994 and $50 \%$ in 1995 . About half of the student whose age between 13 to 17-year-olds access computer to learn

\footnotetext{
+ Corresponding author.

E-mail address:soficitta@gmail.com, harrybs@cs.ui.ac.id, zhasibua@cs.ui.ac.id
} 
mathematics. Fewer students used computers to solve natural science and/or social science problems. Research generally agrees that drill-and-practice forms of computer-assisted instruction are effective in producing achievement gains in students. Research on the adoption of innovations in schools consistently points to the key role of administrators in successful implementation. Effective staff development for teachers should take advantage of telecommunications technologies that allow teachers to interact with each other, take online courses, and easily access the latest information related to their job [1].

Despite many studies have been reported [2-6], most of these reports do not provide step-by-step guideline for adopting ICT in school which make it difficult for a school to replicate the reported achievement. Therefore, the objective of this research is to propose some steps on how to identify and evaluate these ICT adoption components using data-driven (bottom-up) approach as a preliminary steps toward ICT adoption in school. This method is tested using primary data from schools in Indonesia.

\section{Literature Review}

In the past two decades, there have been many studies conducted to explore many aspects of ICT adoption in education. For example, Zain et. al. in 2004 reported common ICT adoption in schools for school administration such as student assessment records, scheduling and administration. This practice is common example of how ICT has affected school by introducing ICT-based school management [2]. Further study carried out by Langrova and Poulova shows a number of evidences that adoption of modern ICTs in teaching and learning process is necessary and useful for both teachers and students [3].

Another study confirmed previous studies which concludes that ICT has huge potential to helps teachers and their students to connect to the knowledge they require without geographical boundaries. However, financial and human resources have become common barriers to make ICT adoption practical in many schools. As a result, the impact of ICT adoption in education is highly determined by solutions to overcome those challenges [4].

The study conducted by Hepp [5] and Sooryanarayan and Rekha [6] involving some developing countries as samples of their studies conclude that ICT policy in education is an important and a key success factor of ICT adoption in schools. In their reports, they argue that designing an ICT policy for school is a far more complex task than merely deploying hardware in the schools [5 \& 6]. Although many success reports on ICT adoption in schools in many countries have been widely available in literatures in the past ten years, policy makers in developing countries cannot blindly replicate ICT adoption in school from a country elsewhere. Both of the studies show some evidences that there are several local conditions or critical factors which should be taken into account at the national, school, teacher and student levels. Although some of these factors are all of a general nature and therefore applicable in many different contexts, policy makers should not take them as a universal recipe, rather than take then as only a framework for designing a policy [5]. In the same spirit, Sooryanarayan and Rekha [6] conclude that ICT adoption in school is not just adopting free or open-source system.

With such rapid growth of ICT throughout the world, ICTs have been sparking a new creativity spirit, the creation of innovative products and services and increased productivity in education systems. Wang and Zhou [7] argue that to achieve a greater impact of ICT adoption in education systems require new approaches to teaching and learning and new types of technologies to support those new approaches.

The study conducted by Zahariev, Ruseva, Hristov and Bencheva confirm that, whilst ICT convergence in many forms has strengthen ICT industry and education institution, it has raised challenge to both instructors and students. Many evidences show that the development of cloud computing services and other modern ICT systems and technologies have huge impact on the education methods and processes. Current integration of Internet with information technology and communication technology is transforming both industry and education and is enabling the development of new technologies providing the possibility to implement these technologies for the next generation of educational systems and approaches [8].

To sum up, these studies on ICT adoption in schools can be summarized in Table 1 as follows. There are six components of ICT adoption in education: infrastructure, application, user skill, utilization, financial (budget), and policy. 
Table 1: ICT Adoption Component Summary

\begin{tabular}{|l|c|c|c|c|c|c|c|}
\hline Literature & $\begin{array}{c}\text { Langrova P. } \\
\text { and Poulova } \\
\text { R. } 2013\end{array}$ & $\begin{array}{c}\text { Arshad. M. } \\
\text { and Noman } \\
\text { Saeed M. } \\
2014\end{array}$ & $\begin{array}{c}\text { Zain M. Z. M., } \\
\text { Murugaiah P., Atan } \\
\text { H. and Idrus R. M. } \\
\text { Component }\end{array}$ & $\begin{array}{c}\text { Hepp } \\
\text { P. } \\
2003\end{array}$ & $\begin{array}{c}\text { Sooryanarayan D. } \\
\text { G. and Rekha S. } \\
2014\end{array}$ & $\begin{array}{c}\text { Wang F. } \\
\text { and Zhou } \\
\text { C. 2013 }\end{array}$ & $\begin{array}{c}\text { Ruseva Y., Hristov } \\
\text { G.; and Bencheva } \\
\text { N. 2013 }\end{array}$ \\
\hline infrastructure & $\mathrm{X}$ & $\mathrm{X}$ & $\mathrm{X}$ & $\mathrm{X}$ & $\mathrm{X}$ & $\mathrm{X}$ & $\mathrm{X}$ \\
\hline application & $\mathrm{X}$ & $\mathrm{X}$ & $\mathrm{X}$ & $\mathrm{X}$ & $\mathrm{X}$ & $\mathrm{X}$ \\
\hline user skill & $\mathrm{X}$ & $\mathrm{X}$ & $\mathrm{X}$ & $\mathrm{X}$ & $\mathrm{X}$ & $\mathrm{X}$ \\
\hline utilization & & $\mathrm{X}$ & $\mathrm{X}$ & $\mathrm{X}$ & $\mathrm{X}$ & $\mathrm{X}$ \\
\hline policy & & $\mathrm{X}$ & $\mathrm{X}$ & $\mathrm{X}$ & $\mathrm{X}$ & $\mathrm{X}$ \\
\hline financial & & & & $\mathrm{X}$ & $\mathrm{X}$ \\
\hline
\end{tabular}

Most studies discuss about infrastructure, application, and user skill. It is an ordinary case because infrastructure, application and user skill components existence can be seen more evident. Policy components is very rarely mentioned and mostly just discussing in a small portion as a part of research. But Hepp strongly recommended that it is necessary to include in any ICT in education policy in order to foster quality improvements, so policy makers should not take them as a universal recipe, rather than take then as only a framework for designing a policy [5]. Likewise Sooryanarayan and Rekha said that the ICT policy of educational institutions must incorporate formal evaluation of open-source software alternatives while purchasing application software [6]. They want to share policy components regarding ICT adoption in education.

ICT also provides a distinct advantage to learning by transforming every aspect of the learning contents. Adapting ICT resources into the learning process helps increasing the learner competitive advantages by improving the quality of their learning services and help the student reach to the various learning contents available in electronic format on the web [9].

\section{The Method}

\subsection{Participants}

The 543 respondents are the principals of school scattered in various regions in Indonesia as detailed in Table 2. They are grouped by school level: elementary school (SD), junior secondary school (SMP), high school (SMA), and vocational high school (SMK). Respondents are from 32 provinces out of 34 provinces in Indonesia. The respondents are mostly from Jawa Timur province.

Table 2: Respondents map by province and schools

\begin{tabular}{|c|c|c|c|c|c|c|c|c|c|c|c|c|c|}
\hline No & Province & SD & SMA & SMK & SMP & Total & No & Province & SD & SMA & SMK & SMP & Total \\
\hline 1 & Aceh & 6 & 1 & 3 & 4 & 14 & 17 & Lampung & 6 & 1 & 1 & 8 & 16 \\
\hline 2 & Bali & & & & 1 & 1 & 18 & Maluku Utara & & & & 1 & 1 \\
\hline 3 & Bangka Belitung & & & & 1 & 1 & 19 & NTB & 2 & & & & 2 \\
\hline 4 & Banten & 7 & & & 7 & 14 & 20 & NTT & & & 1 & 2 & 3 \\
\hline 5 & Bengkulu & & & & 4 & 4 & 21 & Papua & & 1 & & & 1 \\
\hline 6 & DKI. Jakarta & 2 & & & 18 & 20 & 22 & Papua Barat & & & & 2 & 2 \\
\hline 7 & Gorontalo & 1 & & & 1 & 2 & 23 & Riau & & & & 1 & 1 \\
\hline 8 & Jambi & 3 & & & 3 & 6 & 24 & Sulawesi Barat & & & & 1 & 1 \\
\hline 9 & Jawa Barat & 33 & 3 & & 23 & 59 & 25 & Sulawesi Selatan & 8 & & 2 & 8 & 18 \\
\hline 10 & Jawa Tengah & 34 & 2 & 2 & 27 & 65 & 26 & Sulawesi Tengah & 1 & & & 1 & 2 \\
\hline 11 & Jawa Timur & 98 & 25 & 33 & 103 & 259 & 27 & $\begin{array}{l}\text { Sulawesi } \\
\text { Tenggara }\end{array}$ & & & & 3 & 3 \\
\hline 12 & Kalimantan Barat & 2 & 1 & & 1 & 4 & 28 & Sulawesi Utara & & & & 1 & 1 \\
\hline 13 & Kalimantan Selatan & 2 & & & 2 & 4 & 29 & Sumatera Barat & 2 & & & 3 & 5 \\
\hline 14 & Kalimantan Tengah & 1 & 1 & & 1 & 3 & 30 & Sumatera Selatan & 2 & & & 3 & 5 \\
\hline 15 & Kalimantan Timur & 1 & & & 2 & 3 & 31 & Sumatera Utara & 7 & 2 & & 12 & 21 \\
\hline 16 & Kepulauan Riau & & & & 1 & 1 & 32 & Yogyakarta & 1 & & & & 1 \\
\hline & & & & & & & & Grand Total & 219 & 37 & 42 & 245 & 543 \\
\hline
\end{tabular}




\subsection{Data gathering}

In this study, the researchers use questionnaire with 50 question about ICT adoption at their school. The questionnaire is a web-based form application. They access the questionnaire through internet. All questions of the questionnaire use Likert scale from 1 (weakest) to 10 (strongest). The questions are mostly quantification from qualitative situations.

\subsection{Data preparation for analyzing}

This research process 600 records data set from six components gathered from literature. The researcher did some validation steps such as confirmation or editing without any changes made. Preparation also rejected data with bad characteristic (double, incomplete, empty, fraud, etc). After data set is ready to be processed, 543 record are imported to SPSS software to be analysed.

\subsection{Data analysis}

Data analysis process uses principal component analysis (PCA) which is a statistical procedure that uses an orthogonal transformation to convert a set of observations of possibly correlated variables into a set of values of linearly uncorrelated variables called principal components [10]. The number of principal components is less than or equal to the number of original variables. This transformation is defined in such a way that the first principal component has the largest possible variance (that is, accounts for as much of the variability in the data as possible), and each succeeding component in turn has the highest variance possible under the constraint that it is orthogonal to the preceding components [11].

PCA is mostly used as a tool in exploratory data analysis and for making predictive models. PCA is the simplest of the true eigenvector-based multivariate analyses. Often, its operation can be thought of as revealing the internal structure of the data in a way that best explains the variance in the data. This is done by using only the first few principal components so that the dimensionality of the transformed data is reduced. PCA is closely related to factor analysis.

Process Detail:

a. $\quad$ Sampling data $=543$

b. Variables $=50$

c. Processed by: Dimension Reduction

d. Test Variable: KMO and Bartlett Test

\section{Results}

After processing the data, statistically result show some data status as shown in Table 3 and Table 4 . Table 3 show the KMO and Bartlett's Test. Kaiser-Meyer-Olkin Measure of Sampling Adequacy $=0.962$ means the data is suitable for Factor Analysis. The test measures sampling adequacy for each variable in the model and for the complete model. Bartlett's Test of Sphericity show Approx. Chi-Square $=78841.189$ means high for degree of freedom $(\mathrm{Df})=49$.

Table 3: KMO and Bartlett's Test

\begin{tabular}{|cc|c|}
\hline \multicolumn{2}{|c|}{ Kaiser-Meyer-Olkin Measure of Sampling Adequacy. } & .962 \\
Bartlett's Test of Sphericity & Approx. Chi-Square & 78841.189 \\
& Df & 49 \\
Sig. & .000 \\
\hline
\end{tabular}

Some components as result reflect seven general components of ICT adoption in Education. Each components has its different weight. $7^{\text {th }}$ components is shown as the last component which the initial eigenvalues is more than 1.00. Initial eigenvalues of $8^{\text {th }}$ components until $50^{\text {th }}$ component are less than 1.00 as shown in Table 4. 
Table 4: Total Variance Explained

\begin{tabular}{|c|c|c|c|c|c|c|c|c|c|}
\hline \multirow{2}{*}{ 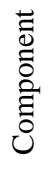 } & \multicolumn{3}{|c|}{ Initial Eigenvalues } & \multicolumn{3}{|c|}{ Extraction Sums of Squared Loadings } & \multicolumn{3}{|c|}{ Rotation Sums of Squared Loadings } \\
\hline & Total & $\begin{array}{c}\% \text { of } \\
\text { Variance }\end{array}$ & Cumulative $\%$ & Total & $\begin{array}{c}\% \text { of } \\
\text { Variance }\end{array}$ & Cumulative $\%$ & Total & $\begin{array}{c}\% \text { of } \\
\text { Variance }\end{array}$ & Cumulative $\%$ \\
\hline 1 & 25.551 & 51.101 & 51.101 & 25.551 & 51.101 & 51.101 & 10.174 & 20.348 & 20.348 \\
\hline 2 & 5.783 & 11.566 & 62.667 & 5.783 & 11.566 & 62.667 & 7.442 & 14.884 & 35.232 \\
\hline 3 & 2.117 & 4.233 & 66.901 & 2.117 & 4.233 & 66.901 & 6.354 & 12.708 & 47.940 \\
\hline 4 & 2.040 & 4.080 & 70.980 & 2.040 & 4.080 & 70.980 & 5.759 & 11.519 & 59.458 \\
\hline 5 & 1.624 & 3.248 & 74.228 & 1.624 & 3.248 & 74.228 & 3.305 & 6.610 & 66.069 \\
\hline 6 & 1.235 & 2.471 & 76.699 & 1.235 & 2.471 & 76.699 & 3.266 & 6.533 & 72.602 \\
\hline 7 & 1.097 & 2.193 & 78.893 & 1.097 & 2.193 & 78.893 & 3.145 & 6.291 & 78.893 \\
\hline
\end{tabular}

The highest seven components and each weight illustrated in Figure 2. Those are (1) ICT Facilities (weight=20.35\%), (2) Utilizing ICT in school administration (weight=14.89\%), (3) Utilizing ICT in teaching and learning (weight=12.71\%), (4) User skill (weight=11.52\%), (5) Policy (weight=6.61\%), (6) Financial (weight $=6.53 \%$ ) and (7) Basic ICT Infrastructure (weight=6.29\%).

Reflected to the case in Indonesia which indeed illustrates the importance of ICT facilities. In recent years, the ministry of education in Indonesia is aggressively seeking to fulfil their needs. It is reported growth of ICT facilities supply (computers, laptop, projector, server, etc) to schools. It is reflected from ICT facilities supply budget, 2015 IDR 98 billion, 2016 IDR 114 billion, and 2017 IDR 425 billion [12]. Internet access supply is also provided to school by the ministry of education in Indonesia. There are 2,329 schools are free connected to internet [13].

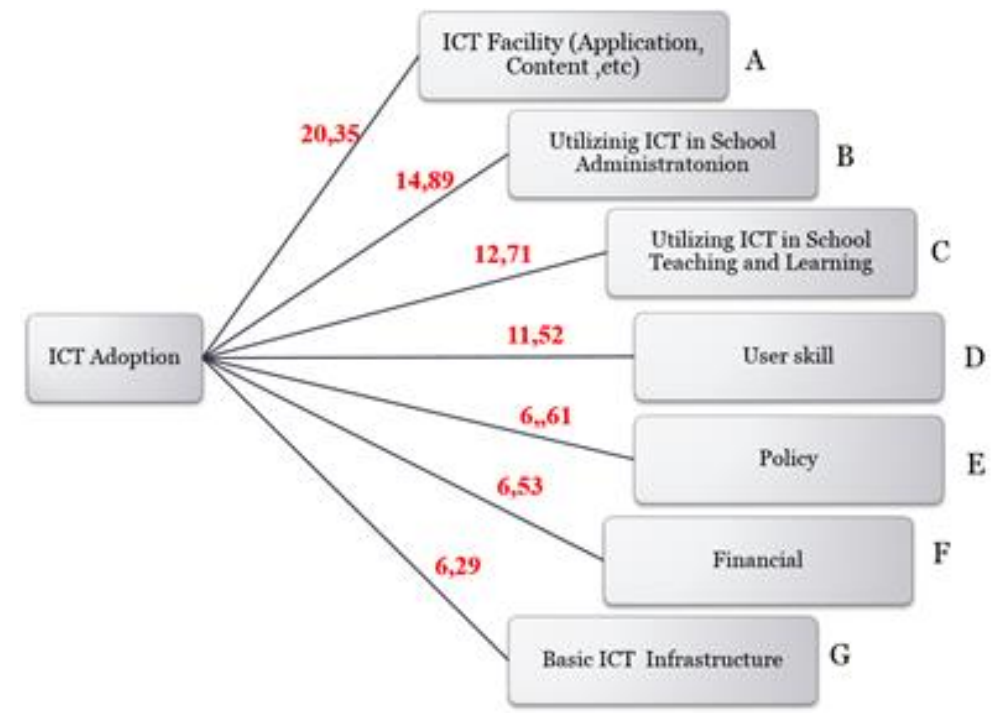

Fig. 2: Seven Components of ICT Adoption in Education

\section{Discussion and Conclusion}

The results of the analysis that has been obtained by the processing of primary data indicates that ICT adoption in education has seven components. Those are (1) ICT Facilities (weight=20.35\%), (2) Utilizing ICT in school administration (weight=14.89\%), (3) Utilizing ICT in teaching and learning (weight=12.71\%), (4) User skill (weight=11.52\%), (5) Policy (weight=6.61\%), (6) Financial (weight=6.53\%) and (7) Basic ICT Infrastructure (weight=6.29\%).

User skill component in ICT adoption in education is also described in details as 3 areas: (1) Competencies focusing on the learning process, (2) Operating skills and (3) Social and ethical competencies [14]. Operating skill means how the teacher or school administration staff can use the ICT equipment. And for another issue in number 3 about social and ethical competencies means how they use ICT in an adequate and a responsible way 
It is concluded that the ICT adoption in education can be more focused in the implementation stage by concerning the strong related components. For further implementation, it is better to consider the critical components. Thus, ICT adoption process can run more effectively and harmoniously towards goal achievement.

There are probably still many other cases among countries in the world. Almost every country has a distinctive process of ICT adoption, including typical in the world of education including in Indonesia, which has an educational system classified into two categories: public schools and religious schools, and other uniqueness which is different among countries. The adoption process was also probably influenced by the culture and politics and high regulation which could have an impact on the adoption of ICT in education. The possibility of many more other components that are very interesting to further study to enhance this research.

\section{References}

[1] Policy Information Center, Educational Testing Service Princeton, New Jersey. Computers and Classrooms: The Status of Technology in U.S. Schools.

[2] Zain M. Z. M., Murugaiah P., Atan H. and Idrus R. M. 2004. Management Practice in Malaysian Smart School: Tasks and Support Analysis of the ICT Implementation Proc. of the IEEE Int. Conf. on Advanced Learning Technologies (ICALT'04).

[3] Langrova P. and Poulova R. 2013. The IT Impact on Primary Education 11th IEEE Int. Conf. on Emerging e Learning Technologies and Applications, The High Tatras, Slovakia.

[4] Arshad. M. and Noman Saeed M. 2014. Emerging Technologies For E-Learning and Distance Learning: A Survey Int. Conf. on Web and Open Access to Learning (ICWOAL), Jazan, Kingdom of Saudi Arabia.

[5] Hepp P. 2003. Critical Factors for an ICT in Education Policy in Developing Countries.

[6] Sooryanarayan D. G. and Rekha S. 2014. Trends in Open Source Software Adoption in Indian Educational Institutions IEEE Sixth Int. Conf. on Technology for Education.

[7] Wang F. and Zhou C. 2013. A Theoretical Study on Development of Information and Communication Technology (ICT)-Supported Education Systems 10th Int. Conf. on Fuzzy Systems and Knowledge Discovery (FSKD).

[8] Zahariev P., Ruseva Y., Hristov G.; and Bencheva N. 2013. ICT Convergence Challenges in Education and their Impact on both Instructors and Students 24th EAEEIE Annual Conf. (EAEEIE), Crete, Greece.

[9] Basha A. D., Umar I. N., Abbas M. 2013. A Sight onthe Use of ICT Resources For E-Learning In The Iraqi Higher Education Institutions (IHEI): A Framework for the Use of ICT in E-Learning.

[10] Abdi. H., \& Williams, L.J. (2010). "Principal component analysis". Wiley Interdisciplinary Reviews: Computational Statistics. 2 (4): 433-459. doi:10.1002/wics.101.

[11] Shaw P.J.A. (2003) Multivariate statistics for the Environmental Sciences, Hodder-Arnold. ISBN 0-340-80763-6.

[12] Rencana Kerja dan Anggaran Kementerian dan Lembaga Kementerian Pendidikan dan Kebudayaan Republik Indonesia, 2015 2016, 2017.

[13] Ministry of Education and Culture, http://sekolah.jardiknas.kemdikbud.go.id/sekolah/schoolnet, accessed Feb 1, 2017).

[14] Tondeur,. Jo, Johan van Braak and Martin Valcke. 2007. Curricula and the use of ICT in education: Two worlds apart? 